\title{
Transcriptome analysis of the responses of Staphylococcus aureus to antimicrobial peptides and characterization of the roles of vraDE and vraSR in antimicrobial resistance
}

\author{
Milla Pietiäinen ${ }^{1}$, Patrice François ${ }^{2}$, Hanne-Leena Hyyryläinen ${ }^{1}$, \\ Manuela Tangomo ${ }^{2}$, Vera Sass ${ }^{3}$, Hans-Georg Sahl ${ }^{3}$, Jacques Schrenzel ${ }^{2}$ and \\ Vesa P Kontinen*1
}

Address: ${ }^{1}$ Antimicrobial Resistance Unit, Department of Infectious Disease Surveillance and Control, National Institute for Health and Welfare (THL), PL 30, 00271 Helsinki, Finland, ${ }^{2}$ Genomic Research Laboratory, Service of Infectious Diseases, University Hospitals of Geneva, University of Geneva, 1211 Geneva-14, Switzerland and ${ }^{3}$ Institute for Medical Microbiology, Immunology and Parasitology, Pharmaceutical Microbiology Unit, University of Bonn, Bonn, Germany

Email: Milla Pietiäinen - milla.pietiainen@thl.fi; Patrice François - patrice.francois@genomic.ch; Hanne-Leena Hyyryläinen - hanne-leena.hyyrylainen@thl.fi; Manuela Tangomo - manuela.tangomo@genomic.ch; Vera Sass - vera.sass@gmx.de; Hans-Georg Sahl - sahl@mibi03.meb.uni-bonn.de; Jacques Schrenzel - jacques.schrenzel@genomic.ch; Vesa P Kontinen* - vesa.kontinen@thl.fi

* Corresponding author

This article is available from: http://www.biomedcentral.com//47/-2/64/10/429

(C) 2009 Pietiäinen et al; licensee BioMed Central Ltd.

This is an Open Access article distributed under the terms of the Creative Commons Attribution License (http://creativecommons.org/licenses/by/2.0), which permits unrestricted use, distribution, and reproduction in any medium, provided the original work is properly cited.

\begin{abstract}
Background: Understanding how pathogens respond to antimicrobial peptides, and how this compares to currently available antibiotics, is crucial for optimizing antimicrobial therapy. Staphylococcus aureus has several known resistance mechanisms against human cationic antimicrobial peptides (CAMPs). Gene expression changes in $S$. aureus strain Newman exposed to linear CAMPs were analyzed by DNA microarray. Three antimicrobial peptides were used in the analysis, two are derived from frog, temporin $\mathrm{L}$ and dermaseptin $\mathrm{K} 4-\mathrm{S} 4(\mathrm{I}-\mathrm{I} 6)$, and the ovispirin-I is obtained from sheep.

Results: The peptides induced the VraSR cell-wall regulon and several other genes that are also up-regulated in cells treated with vancomycin and other cell wall-active antibiotics. In addition to this similarity, three genes/operons were particularly strongly induced by the peptides: vraDE, SA0205 and SASO16, encoding an ABC transporter, a putative membrane-bound lysostaphin-like peptidase and a small functionally unknown protein, respectively. Ovispirin-I and dermaseptin K4-S4(I-I6), which disrupt lipid bilayers by the carpet mechanism, appeared to be strong inducers of the vraDE operon. We show that high level induction by ovispirin-I is dependent on the amide modification of the peptide C-terminus. This suggests that the amide group has a crucial role in the activation of the Aps (GraRS) sensory system, the regulator of vraDE. In contrast, temporin $L$, which disrupts lipid bilayers by forming pores, revealed a weaker inducer of vraDE despite the C-terminal amide modification. Sensitivity testing with CAMPs and other antimicrobials suggested that $\mathrm{VraDE}$ is a transporter dedicated to resist bacitracin. We also showed that SA0205 belongs to the VraSR regulon. Furthermore, VraSR was shown to be important for resistance against a wide range of cell wall-active antibiotics and other antimicrobial agents including the amide-modified ovispirin-I, bacitracin, teicoplanin, cefotaxime and 10 other $\beta$ lactam antibiotics, chlorpromazine, thioridazine and EGTA.
\end{abstract}

Conclusion: Defense against different CAMPs involves not only general signaling pathways but also CAMP-specific ones. These results suggest that CAMPs or a mixture of CAMPs could constitute a potential additive to standard antibiotic treatment. 


\section{Background}

The ubiquitous presence of cationic antimicrobial peptides (CAMPs) in virtually all types of cells and organisms ranging from bacterial cells to humans suggests that CAMPs have important conserved roles as defense weapons. CAMPs contribute to the host defense of microbial invasion on epithelial surfaces by killing engulfed microorganisms in phagocytic cells or modulating inflammatory responses in infections [1-3]. These ancient weapons of host defense are typically amphipathic peptides with a net positive charge at physiological $\mathrm{pH}$ and they share well-defined $\alpha$-helical or $\beta$-sheet secondary structures. CAMPs are able to integrate into cell membranes, form membrane-spanning pores and thereby cause lethal cell damage. The positive charge is important for the initial binding of CAMPs to target membranes. There are differences in the way CAMPs interact with membranes and accordingly three different models have been used to define their mode of actions in model membrane systems [4]. In the barrel-stave mechanism, peptides integrate into the membrane and form membrane-spanning pores [5]. In the toroidal-pore mechanism, CAMPs form membranespanning pores together with intercalated lipids [5]. And in the carpet mechanism, peptides accumulate on the membrane surface in a carpet-like manner and at a threshold density so that they dissolve the membrane without forming transmembrane channels [6]. However, membrane damage is not the only mechanism whereby CAMPs cause cell death. They may also affect functions of several other cell components and act as metabolic inhibitors of cellular processes including biosynthesis of the cell wall, nucleic-acids and proteins $[1,3]$. In these cases, the cell death can be the result of multiple inhibitory effects.

Bacteria have evolved mechanisms to combat the harmful effects of CAMPs [3]. On the other hand, the antimicrobial peptide repertoire in host cells may have co-evolved with the evolution of microbial resistance mechanisms. This is exemplified by the skin of the frog Rana temporaria in which some temporins act in a synergistic manner to overcome the resistance of Gram-negative bacteria imposed by the lipopolysaccharide [7]. The high resistance of Staphylococcus aureus to CAMPs produced by human cells may contribute to epithelial colonization and resistance to destruction by neutrophils. Several mechanisms conferring increased resistance to CAMPs have been identified. The modulation of the density of negative charge in the cell wall by D-alanylation of teichoic acids (Dlt system) or on the outer surface of the cell membrane by L-lysinylation of phosphatidylglycerol (MprF) has been shown to contribute to CAMP resistance in S. aureus $[8,9]$ as well as in several other bacteria [1013]. In Gram-negative bacteria, LPS modifications modulate cell envelope charge and polymyxin susceptibility [14-18]. Many bacteria species produce proteases which cleave antimicrobial peptides, particularly linear ones [3]. S. aureus aureolysin and V8 as well as proteases secreted by Bacillus anthracis are examples of proteases capable of cleaving the human cathelicidin LL-37 $[19,20]$. The CAMP resistance mechanisms also include CAMP-binding proteins and CAMP efflux pumps [21-23].

Bacterial sensory systems are capable of recognizing cationic antimicrobial peptides and to respond to their presence by up-regulation of general stress systems as well as more specific CAMP resistance mechanisms. In Salmonella typhimurium binding of CAMPs to the PhoQ two-component sensor kinase activates the signal transduction cascade from the sensor to the PhoQ response regulator, resulting consequently in the induction of the PhoPQ-regulated promoters [24]. A complex stress response was observed when Bacillus subtilis was exposed to CAMPs, including activation of the SigW and SigM extracytoplasmic sigma factors and the YxdJK and LiaRS two-component systems [25]. In this study, our purpose was to characterize the stress response of $S$. aureus treated with cationic antimicrobial peptides by using whole-genome oligoarrays. The effects of three different $\alpha$-helical CAMPs on the transcriptome of the $S$. aureus Newman strain were analyzed: temporin L, ovispirin-1 and dermaseptin K4S4(1-16). These peptides are synthesized as preproproteins (precursors) and the mature microbicidal peptides are formed after proteolytic cleavage of the pre- (signal peptide) and pro-regions of the precursors [26,27]. Ovispirin-1 is a derivative of the cathelicidin SMAP-29 found in sheep [28]. The other two peptides, dermaseptin K4-S4(1-16), which is a truncated derivative of the dermaseptin S4, and temporin $\mathrm{L}$, are both expressed in amphibian skin $[29,30]$. Temporin L belongs to poreforming peptides (barrel-stave or toroidal pore mechanism) $[30,31]$ and ovispirin-1 and dermaseptin disrupt lipid bilayers by the carpet mechanism [1]. We used these well-characterized peptides of animal origin as models of cationic antimicrobial peptides and expected that studying their interactions with $S$. aureus would give information that was more generally applicable also to human CAMPs. We aimed to identify the CAMP stimulons and to determine whether the differentially expressed genes play a role in CAMP resistance. Furthermore, we were interested to find out whether there are strong peptide-specific responses or a more general stress response triggered by CAMPs exposition, to explore the mode of action of CAMPs and to improve our understanding of the resistance mechanisms against CAMPs.

\section{Results \\ The VraSR cell wall regulon, vraDE, SA0205 and SAS0I6 are strongly induced by cationic antimicrobial peptides}

Exponentially growing $S$. aureus cells were treated with Cterminally amidated temporin $\mathrm{L}$ (temporin $\mathrm{L}-\mathrm{NH}_{2}$ ), 
ovispirin-1 (ovispirin-1- $\mathrm{NH}_{2}$ ) or dermaseptin K4-S4(116) (dermaseptin $\mathrm{K} 4-\mathrm{S} 4(1-16)-\mathrm{NH}_{2}$ ) at sublethal concentrations (see Methods) which slightly inhibited growth but did not stop it. Gene expression changes in the CAMPtreated cells as compared to non-treated cells were analyzed by using whole-genome oligoarrays.
All three peptides upregulated a large number of genes (63-247) and most of them were induced by more than one peptide. Table 1 shows a set of the genes induced by at least one of the peptides at least 3-fold and represents a list of "marker" genes for the CAMP stimulon. The complete list of the induced genes (higher than 2-fold induc-

Table I: Genes induced by cationic antimicrobial peptides.

\begin{tabular}{|c|c|c|c|c|c|c|}
\hline \multirow[t]{2}{*}{ Gene ID } & \multirow[t]{2}{*}{ Gene name* } & \multicolumn{3}{|c|}{ Induction with** } & \multirow[t]{2}{*}{ Known regulation*** } & \multirow[t]{2}{*}{ Protein/Similarity } \\
\hline & & $\mathbf{T}$ & $\mathbf{0}$ & D & & \\
\hline SA00II & & 3.5 & 2.1 & & & Similar to homoserine-o-acethyltransferase \\
\hline SAOI 22 & butA & 3.2 & 2.1 & & VCM & Acetoin reductase \\
\hline SA0205 & & 17.2 & 11.2 & 6.2 & VCM & Similar to lysostaphin precursor \\
\hline SA0344 & metE & 4.5 & 2.3 & & VCM & $\begin{array}{l}\text { 5-methyltetrahydropteroyltriglutamate-homocysteine } \\
\text { methyltransferase }\end{array}$ \\
\hline SA0428 & & 3.6 & 2.4 & 2.3 & & Hypothetical protein \\
\hline SA0430 & gltB & 4.4 & 2.5 & & & Glutamate synthase large subunit \\
\hline SA0480 & ctsR & 4.2 & 4.2 & & & Transcription repressor of class III stress genes homologue \\
\hline SA05I3 & & 3.3 & 2.2 & & & Conserved hypothetical protein \\
\hline SA059I & & 3.0 & 3.3 & 2.1 & VCM & Hypothetical protein \\
\hline SA0677 & & 3.6 & 2.1 & & VCM & Similar to choline transport ATP-binding protein \\
\hline SA078I & & 3.1 & 2.1 & & & Similar to 2-nitropropane dioxygenase \\
\hline SA08I7 & & 5.0 & 2.7 & & & Similar to NADH-dependent flavin oxidoreductase \\
\hline SA0825 & spsA & 2.6 & 3.5 & 2.0 & VraSR, VCM & Type-I signal peptidase \\
\hline SA0835 & $c l p B$ & 3.9 & 4.1 & & VCM & ClpB chaperone homologue \\
\hline SA0845 & oppB & 4.3 & 2.0 & & VCM & Oligopeptide transport system permease protein \\
\hline SA0903 & & 2.1 & 4.1 & 2.6 & & Conserved hypothetical protein \\
\hline SAII64 & dhoM & 5.2 & 2.8 & & VCM & Homoserine dehydrogenase \\
\hline SAII70 & katA & 4.3 & 2.6 & & & Catalase \\
\hline SA 1216 & & 3.8 & 2.4 & & & Similar to oligoendopeptidase \\
\hline SAI219 & & & 5.4 & 4.2 & & Similar to phosphate $A B C$ transporter \\
\hline SAI 227 & $\operatorname{dapA}$ & 8.3 & 9.6 & & VCM & Dihydrodipicolinate synthase \\
\hline SAI254 & & 3.1 & 3.5 & & VraSR, VCM & Hypothetical protein \\
\hline SAI476 & & 4.2 & 5.3 & 3.3 & VraSR, VCM & Hypothetical protein \\
\hline SAI5I7 & citC & 4.9 & 5.8 & 3.1 & VCM & Isocitrate dehydrogenase \\
\hline SAI545 & serA & 4.6 & 2.5 & & VCM & Similar to soluble hydrogenase $\mathbf{4 2} \mathrm{kD}$ subunit \\
\hline SAI549 & htrA & 2.9 & 3.0 & 2.0 & VraSR, VCM & Similar to serine proteinase Do, heat-shock protein HtrA \\
\hline SAI599 & & 3.2 & 2.4 & & & Similar to transaldolase \\
\hline SAI655 & ecs $A$ & 3.0 & 3.0 & & & $A B C$ transporter EcsA homologue \\
\hline SAI659 & prsA & 3.2 & 4.5 & 2.9 & VraSR, VCM & Peptidyl-prolyl cis/trans isomerase homologue \\
\hline SAI70I & vraS & 3.9 & 5.3 & 2.5 & VraSR, VCM & Two-component sensor histidine kinase \\
\hline SAI820 & & 3.6 & 3.0 & 2.2 & & Similar to bacteriophage terminase small subunit \\
\hline SAI836 & groEL & 3.8 & 4.3 & 2.2 & & GroEL protein \\
\hline SAI862 & leuA & 13.5 & 3.3 & 2.1 & & 2-isopropylmalate synthase \\
\hline SAI990 & & 3.4 & 2.6 & 2.2 & & Conserved hypothetical protein \\
\hline$S A 2113$ & & 2.2 & 3.7 & 2.2 & VraSR, VCM & Hypothetical protein \\
\hline SA2221 & & 2.4 & 3.2 & & VraSR, VCM & Hypothetical protein \\
\hline SA2304 & $f b p$ & 4.8 & 2.4 & & VCM & Fructose-bisphosphatase \\
\hline SA2324 & & 4.9 & 2.6 & 2.0 & & Similar to thioredoxin \\
\hline SA2343 & & 4.3 & 4.3 & 2.7 & VraSR, VCM & Hypothetical protein \\
\hline SA2397 & & 3.5 & 2.3 & & VCM & Similar to pyridoxal-phosphate dependent aminotransferase \\
\hline SA2467 & hisH & 40.1 & 4.3 & & VCM & Amidotransferase HisH \\
\hline SA2492 & vraD & 8.2 & 32.4 & 17.2 & VCM & Similar to ABC transporter \\
\hline SASOI6 & & 5.0 & 7.4 & 5.4 & VCM & Hypothetical protein \\
\hline
\end{tabular}

*: Only the most strongly upregulated genes, the marker genes of the CAMP stimulon, are shown in this table. The complete list of genes induced at least 2-fold by several CAMPs is shown in additional file $\mathrm{I}$. In the case of operons, only the first gene or the most strongly induced gene is shown; **: T, temporin L- $\mathrm{NH}_{2} ; \mathrm{O}$, ovispirin-I-NH $\mathrm{N}_{2}$; D, dermaseptin $\mathrm{K} 4-\mathrm{S} 4(\mathrm{I}-\mathrm{I} 6)-\mathrm{NH}_{2}$;

***: VCM, vancomycin inducible; VraSR, belongs to the VraSR regulon. 
tion) is shown in additional file 1. The microarray data sets have been deposited in the GEO database (GPL7137 and GSE15800 for the complete microarray dataset) [32].

CAMPs induced the expression of the VraSR two-component system and consequently almost the whole VraSR regulon [33] was upregulated. In addition to the three antimicrobial peptides of animal origin, we also recently found that the human cathelicidin LL-37 induces the VraSR regulon (data not shown). Among the most strongly induced genes were vraDE, SA0205 and SAS016, which encode an ABC-type transporter similar to a putative bacitracin efflux pump [34,35], a lysostaphin-like cell-wall peptidase and a functionally-unknown peptide of 55 amino acids, respectively. The antimicrobial peptide treatment caused stress that induced general stress genes such as the ctsR-clpC operon, groELS and $d n a J K$. The synthesis of cell components involved in combating oxidative stress, catalase (SA1170), a putative thioredoxin (SA2324) and thioredoxin reductases $(\operatorname{tr} x B)$, were also among the induced genes. Furthermore, a feature of the transcriptome was upregulation of several amino acidbiosynthesis operons (dap, his, leu, and thr operons).

\section{Genes involved in anaerobic energy metabolism or encoding virulence factors were down-regulated in CAMP-treated cells}

There were also down-regulated genes in the transcriptomes. Temporin $\mathrm{L}-\mathrm{NH}_{2}$, ovispirin-1- $\mathrm{NH}_{2}$ and dermaseptin K4-S4(1-16)- $\mathrm{NH}_{2}$ decreased the expression of 219, 194 and 134 genes, respectively. Most of the genes were downregulated by more than one peptide (additional file 2). Notably, all three peptides had a strong inhibitory effect on the expression of genes involved in energy metabolism under anaerobic conditions [36]. The genes encoding enzymes for nitrate respiration (nar and nas operons) and fermentation ( $p f l P, p f l A, i c t E$, and adh1) were strongly repressed. Another striking phenomenon is that antimicrobial peptides caused down-regulation of several virulence factors and their regulators (saeRS and agr). Among the down-regulated virulence factor genes were $h l d, s s a A$, sbi, hlgA, ssl11 (set15), clfA, clfB and spa. The negative effect was particularly strong on the expression of hld, ssl11, clfA and $c l f B$ in cells treated with ovispirin-1- $\mathrm{NH}_{2}$.

\section{qRT-PCR measurements of the differentially expressed genes}

We used qRT-PCR to verify some of the most interesting gene expression responses. The most strongly upregulated genes of the transcriptome,vraD (SA2492), SA0205 and SAS016 were subjected to qRT-PCR. The activity of the VraSR regulon was determined with three genes, vraS (SA1701), prsA (SA1659) and SA1477. The DNA microarray data suggested that an operon encoding a putative PstB-like phosphate uptake system (SA1217-SA1221) was induced by ovispirin-1- $\mathrm{NH}_{2}$ and dermaseptin K4-S4(116) $-\mathrm{NH}_{2}$ but not by temporin $\mathrm{L}-\mathrm{NH}_{2}$ (Table 1 and additional file 1). This induction pattern suggests that the peptide-induced expression from the promoter of the SA1217-SA1221 operon may depend on the mode of action of the antimicrobial peptides and we therefore were interested in confirming the peptide-specific induction pattern by qRT-PCR. We determined the expression level of SA1220. We also determined two further genes, vraF (SA0616) and dltA (SA0793), which were induced about 2-fold in the microarrays only by ovispirin-1- $\mathrm{NH}_{2}$. The ortholog of vraF in B. subtilis is bceA, which encodes the ATPase component of an ABC transporter. Since bceA is strongly induced by bacitracin [34] and moderately by linear cationic antimicrobial peptides [25], and since it is also important for bacitracin resistance, we were interested in determining whether vraF is induced in the CAMP-treated cells of $S$. aureus. Furthermore, vraDE, vraFG and the dlt operon are all regulated by the Aps (or GraRS) sensory system [37]. The dlt operon encodes proteins which modify wall teichoic acids and lipoteichoic acids with D-alanine and thereby modulate the cell wall charge [9]. The density of negative charge in the wall affects the sensitivity of the bacteria to CAMPs.

The gene expression changes of the induced genes were clearly higher in the qRT-PCR measurements than in the DNA microarray, a previously described characteristic $[38,39]$, but overall consistency was found in the results. The SAS016, vraD, SA0205, SA1477 and prsA genes exhibited the strongest gene induction responses; over 100-fold induction of SAS016 and vraD was observed with ovispirin-1- $\mathrm{NH}_{2}$ (Figure 1). Most of the genes responded more strongly to ovispirin-1- $\mathrm{NH}_{2}$ than temporin-L-NH$H_{2}$. This was particularly clear in the induction of $v r a D$ and SA1220, but also vraF, dltA, prsA, SAS016 and SA1477 responded in this manner. SA0205 was the only gene which was expressed at higher levels in temporin-L- $\mathrm{NH}_{2}$ treated cells as compared to ovispirin-1- $\mathrm{NH}_{2}$-treated cells. The gene expression responses to dermaseptin K4-S4(116) $-\mathrm{NH}_{2}$ were in most cases similar to those of ovispirin$1-\mathrm{NH}_{2}$.

The negative effect of CAMPs on the expression of $s s a A, s b i$ and SA0423 was verified by qRT-PCR. Consistently with the microarray results, these genes were down-regulated in cells treated with the peptides (Figure 1). However, the decrease in expression was clearly lower in the qRT-PCR measurements.

\section{The amide at the C-terminus of ovispirin-I is crucial for the high level induction of vraDE}

The three peptides used in the DNA microarray analysis were modified with C-terminal amide groups. We studied whether the amide affects gene induction by comparing 


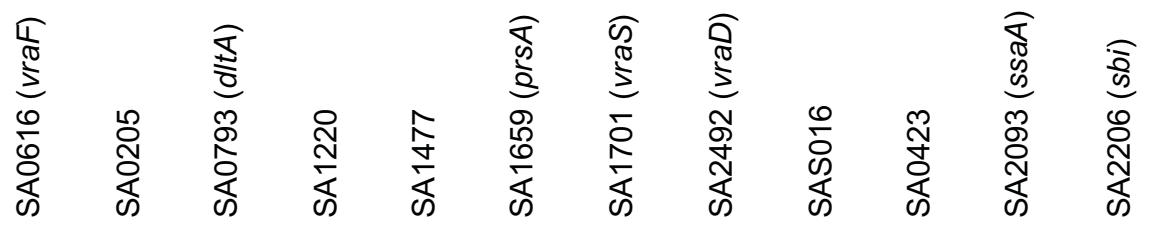

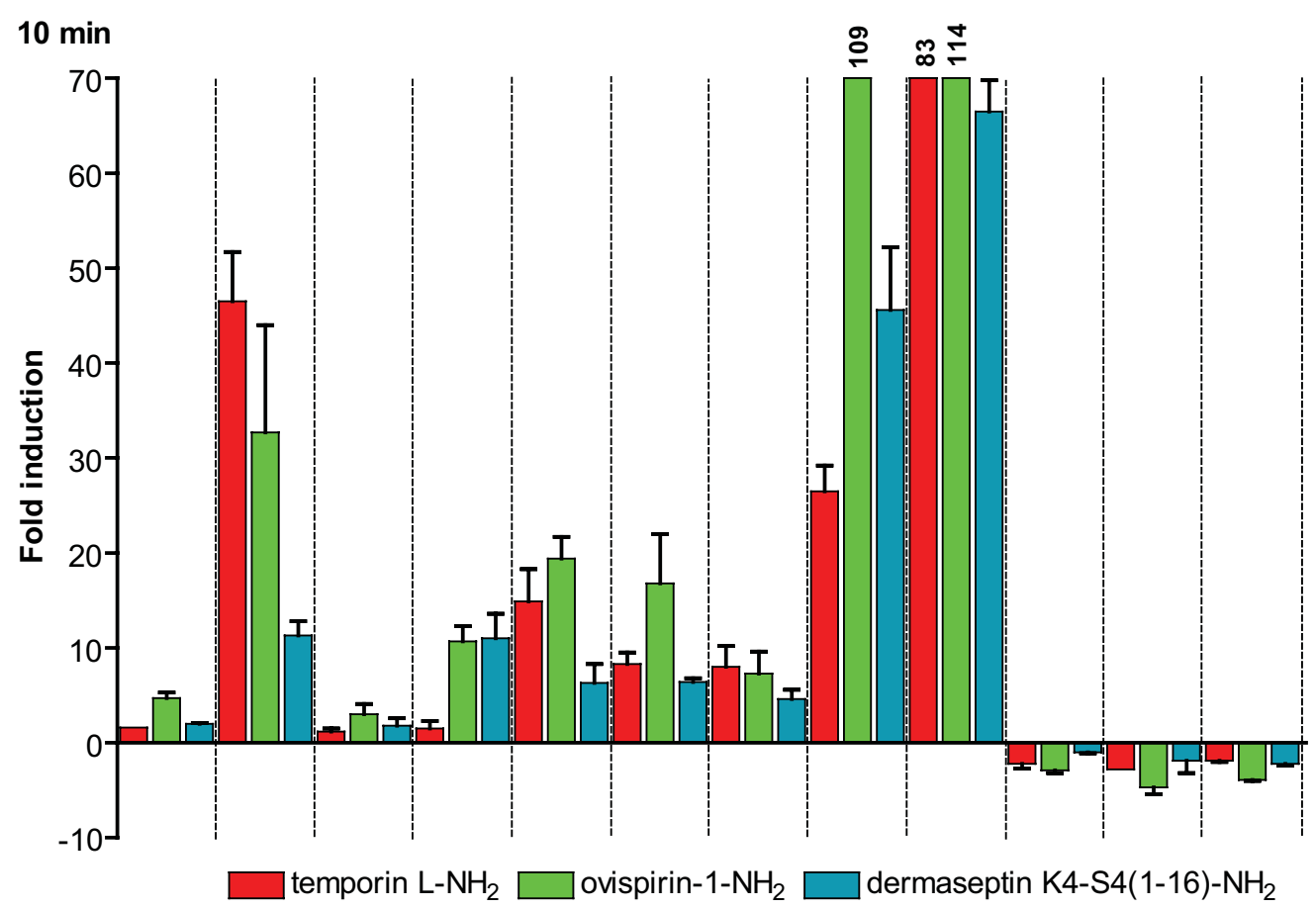

Figure I

Induction or repression of genes in cells treated with cationic antimicrobial peptides as determined by qRTPCR. The measurements of a set of differentially expressed genes were performed after 10 min treatments. The standard

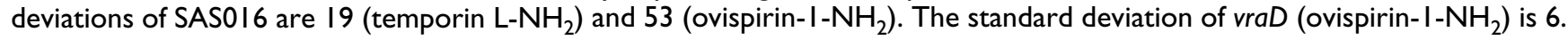

the induction levels of four key genes in cells treated with amide-modified or non-modified ovispirin-1 or amidemodified temporin $\mathrm{L}$. The determined genes were groEL, a general stress gene, prsA, the activity of which reflects the activity of the VraSR two-component system and the severity of the stress in the cell wall [33], and SA0205 and vraD, which were strongly induced by CAMPs. We also determined how other types of antimicrobial agents induce these genes. The antimicrobial agents were vancomycin and teicoplanin, which inhibit cell wall biosynthesis by interacting with the lipid II peptidoglycan precursor [40], bacitracin, an antimicrobial agent which interferes with the dephosphorylation of the peptidoglycan precursor [41], and daptomycin, a lipopeptide antibiotic with a specific mode of action on the cell membrane [42]. Furthermore, a pentaglycin peptide, A(D-Glu)K(DAla)GGGGGA(D-Glu)K(D-Ala), which mimics the peptide cross-link of $S$. aureus peptidoglycan, was tested to see whether a native cell wall peptide induces the expression of the four genes. This peptide was not antimicrobial at the concentration used, $20 \mu \mathrm{g} / \mathrm{ml}$.

The results revealed that the C-terminal amide strongly influenced the induction of vraD by ovispirin-1. In the absence of the amide, vraD was only induced 3.7-fold (Table 2). In contrast, when ovispirin-1 was modified with the amide, vraD was induced 136-fold. The MIC values of both of the ovispirin-1 peptides for the $S$. aureus Newman strain were $20 \mu \mathrm{g} / \mathrm{ml}$ (Table 3), indicating that a difference in the stability of the peptides does not explain the large difference (about 35-fold) in the induction levels. The amide-modified peptide was also a better inducer of SA0205, prsA and groEL, but the difference was much smaller, only 2-4-fold. The induction pattern of the cell wall antibiotics vancomycin and teicoplanin was similar to that of ovispirin-1 without the C-terminal amide: the induction levels of SA0205 and prsA were clearly higher than those of vraD and groEL. The vraD expression was also strongly induced by bacitracin, almost 500-fold, 
whereas the induction levels of SA0205 and prsA were much lower, 30-50-fold. Thus the induction pattern was similar to the amide-modified ovispirin-1. In contrast, temporin $\mathrm{L}-\mathrm{NH}_{2}$, despite the C-terminal amide and lower MIC than ovispirin-1- $\mathrm{NH}_{2}$, was a poor inducer of $v \mathrm{raD}$ (Table 2, Figure 1) and resembled in this respect the nonmodified ovispirin-1 and the cell wall antibiotics. The pentaglycine peptide did not induce any of the four genes.

\section{VraDE is an $A B C$ transporter system dedicated to resist bacitracin, whereas VraSR two-component system affects the resistance against $a$ wider spectrum of antimicrobial agents}

Our experiments showed that the VraDE ABC transporter and the VraSR two-component system are two CAMPinducible systems which could be important for bacterial cells in resisting the harmful effects of CAMPs and possibly other antimicrobial agents. In order to study this, we constructed vraDE and vraSR null mutants and cultivated the mutants and the parental $S$. aureus Newman strain in Mueller-Hinton broth in the presence of various concentrations of the antimicrobials (two-fold serial dilutions) and determined their MIC values (Table 3). The CAMPs used in the susceptibility tests were, ovispirin-1- $\mathrm{NH}_{2}$, ovispirin-1, temporin $\mathrm{L}_{-} \mathrm{NH}_{2}$, two lantibiotics nisin and Pep5, human cathelicidin LL-37, and hBD3 defensin (the latter three are not shown in Table 3). In addition, we determined MICs for vancomycin, teicoplanin, bacitracin and daptomycin.

The mutations were verified by PCR (see methods), but also the expression of the vraD, SA0205, prsA and groEL genes in the vraDE and vraSR null mutants exposed to vancomycin was determined by qRT-PCR. The $\triangle v r a D E$ mutant did not express vraD mRNA, consistent with the mutation (Table 4). The SA0205, prsA and groEL genes were expressed at about the same level as in the wild-type, 3-60-fold induction (Tables 4). In the $\Delta v r a S R$ mutant, SA0205 and prsA were expressed at a low level (3-fold induction) consistent with the VraSR defect and suggesting that not only prsA but also SA0205 belong to the VraSR regulon. Their induction at a low level in the absence of VraSR may indicate that the expression is also controlled by another sensory system.

The $\triangle v r a D E$ mutant was clearly more sensitive than the wild-type strains to bacitracin (about 10-fold difference in MIC), but no other differences were observed in the antimicrobial sensitivities. This strongly suggests that $\mathrm{VraDE}$ is a bacitracin-specific detoxification pump. More differences were observed with the $\Delta v r a S R$ mutant. It exhibited increased sensitivity to teicoplanin (4-fold difference), bacitracin (4-fold difference) and ovispirin-1- $\mathrm{NH}_{2}$ (2-fold difference). The $\Delta v r a S R$ mutation did not affect the sensitivity to ovispirin-1, nisin, daptomycin, Pep5, LL-37 or hBD3. The same mutations in another $S$. aureus strain (RN4220) caused similar antimicrobial sensitivity differences, indicating that they are not strain specific (additional file 3 ).

In order to characterize further the phenotypes of the vraDE and vraSR null mutants, we subjected them to phenotype microarray (PM) analysis (Biolog). The analysis was performed with the PM11-20 sensitivity plates, which

Table 2: Induction of vraD, SA0205, prsA and groEL in S. aureus cells treated with peptides or cell wall-active antibiotics.

\begin{tabular}{|c|c|c|c|c|}
\hline \multirow[t]{3}{*}{ Antimicrobial agent and concentration** } & \multicolumn{4}{|c|}{ Fold induction* } \\
\hline & \multicolumn{4}{|c|}{ Gene } \\
\hline & vraD & SA0205 & prsA & groEL \\
\hline $\begin{array}{l}\text { Ovispirin-I } \\
100 \mu \mathrm{g} / \mathrm{ml}\end{array}$ & $3.7(0.5)$ & $5.1(1.0)$ & $7.2(1.6)$ & $2.5(0.5)$ \\
\hline $\begin{array}{l}\text { Ovispirin-I-NH } \\
100 \mu \mathrm{g} / \mathrm{ml}\end{array}$ & I $36.7(8.7)$ & $20.0(0.7)$ & $30.7(1.7)$ & $3.8(0.4)$ \\
\hline $\begin{array}{l}\text { Temporin-L-NH }{ }_{2} \\
2 \mu \mathrm{g} / \mathrm{ml}\end{array}$ & $4.6(1.3)$ & I5.I (3.6) & $6.4(1.8)$ & $4.0(0.1)$ \\
\hline $\begin{array}{l}\text { Bacitracin } \\
100 \mu \mathrm{g} / \mathrm{ml}\end{array}$ & $467.5(15.3)$ & $51.4(0.8)$ & $27.9(4.5)$ & $3.6(0.1)$ \\
\hline $\begin{array}{l}\text { Vancomycin } \\
5 \mu \mathrm{g} / \mathrm{ml}\end{array}$ & $6.6(0.6)$ & $25.5(1.8)$ & $32.7(1.7)$ & $1.9(0.0)$ \\
\hline $\begin{array}{l}\text { Teicoplanin } \\
2.5 \mu \mathrm{g} / \mathrm{ml}\end{array}$ & $2.5(0.3)$ & $35.7(6.9)$ & $32.1(4.1)$ & $3.0(0.3)$ \\
\hline $\begin{array}{l}\text { Pentaglysin } \\
20 \mu \mathrm{g} / \mathrm{ml}\end{array}$ & $1.0(0.0)$ & $1.3(0.1)$ & $1.3(0.0)$ & I.I (0.0) \\
\hline
\end{tabular}

*: The ratio of the expression level of the gene in S. aureus Newman treated for 10 minutes with the antimicrobial agent or peptide to that in untreated cells as determined by qRT-PCR. The induction ratios are means from three experiments. The standard deviations are in parenthesis; **: The concentrations of the antimicrobials and peptides used in the analysis are $5 \times$ MIC (see Table 3) with the exception of temporin-L-NH${ }_{2}$, which was used at a subinhibitory concentration, and pentaglycine, which was not microbicidal at the $20 \mu \mathrm{g} / \mathrm{ml}$ concentration. 
Table 3: Antimicrobial sensitivity of the $\triangle v r a D E$ and $\triangle v r a S R$ mutants and their parental strain S. aureus Newman.

\begin{tabular}{lccc}
\hline Antimicrobial agent & & MIC $\left(\mu \mathbf{g ~ m}^{-1}\right)$ & \\
\cline { 2 - 4 } & $\Delta$ vraSR/S. aureus Newman & $\Delta$ vraDE/S. aureus Newman & S. aureus Newman \\
\hline Ovispirin-I & 20 & 20 & 20 \\
Ovispirin-I-NH $\mathrm{NH}_{2}$ & 10 & 20 & 20 \\
Temporin L-NH & 6 & 6 & 6 \\
Nisin & 6.25 & 6.25 & 2.25 \\
Bacitracin & 5 & 2.5 & 2.5 \\
Daptomycin & 2.5 & 0.5 & 0.5 \\
Teicoplanin & 0.125 & 1 & 1 \\
Vancomycin & $\mathrm{I}$ & 1 & \\
\hline
\end{tabular}

allow the testing of 960 phenotypes and the identification of increased or decreased sensitivities of the mutants as compared to the wild-type reference strain to a wide variety of non-peptide antimicrobial agents. Phenotype microarray analysis measures the reduction of tetrazolium dye (see experimental section).

The $\Delta v$ raSR mutant was more sensitive than the wild-type strain to a number of cell wall-active antibiotics including several cephalosporins (additional files 4 and 5). This result is consistent with a similar result of a previous study on a vraSR null mutant of $S$. aureus N315 [33]. The PM assay also suggested enhanced sensitivity to some other antimicrobial compounds than antibiotics. We verified the growth inhibitory effects of four of these antimicrobials, cefotaxime, chlorpromazine, EGTA and sodium tungstate, by cultivating the $\triangle v r a S R$ mutant and the wild-type $S$. aureus Newman strain in BHI medium on microtiter plates containing $0.31 \mu \mathrm{g} / \mathrm{ml}, 0.8 \mathrm{mM}, 31.25 \mu \mathrm{g} / \mathrm{ml}$ and $25 \mathrm{mM}$ concentrations of these antimicrobials, respectively, and measuring the optical densities of the cultures. The $\Delta v r a S R$ mutant was unable to grow in the presence of these antimicrobials, while the wild-type strain grew significantly (Figure 2). In addition to these major differences of sensitivity, several minor differences were also

Table 4: Induction of vraD, SA0205, prsA and groEL in S. aureus $\triangle v r a S R$ and $\triangle v r a D E$ mutants treated with vancomycin.

\begin{tabular}{lcccc}
\hline Mutant & \multicolumn{4}{c}{ Fold induction* } \\
\cline { 2 - 5 } & \multicolumn{4}{c}{ Gene } \\
\cline { 2 - 5 } & vraD & SA0205 & PrsA & groEL \\
\cline { 2 - 5 } & $7.9(0.2)$ & $2.5(0.2)$ & $3.2(0.1)$ & $2.1(0.1)$ \\
$\Delta v r a S R$ & not expressed & $60.4(2.1)$ & $36.0(0.7)$ & $3.1(0.4)$ \\
wild type & $6.6(0.6)$ & $25.5(1.8)$ & $32.7(1.7)$ & $1.9(0.0)$ \\
\hline
\end{tabular}

*: The ratio of the expression level of the gene in the mutant or the wild-type strain treated for 10 minutes with $5 \mu \mathrm{g} / \mathrm{ml}$ of vancomycin to that in untreated cells as determined by qRT-PCR. The induction ratios are means from three experiments. Standard deviations are in parenthesis. observed, but we did not verify them in microtiter plate cultures by optical density measurements. The vraSR null mutant was resistant to macrolide antibiotics due to the ery gene used in the mutant construction. The PM analysis of the $\triangle v r a D E$ mutant did not reveal any significant sensitivity differences (not shown), suggesting again a dedicated role for VraDE in bacitracin resistance.

\section{Discussion}

A prominent feature of the CAMP transcriptomes of $S$. aureus Newman was the induction of the VraSR regulon. The regulon consists of several genes involved in cell wallassociated functions such as protein quality control, protein folding and modulation of cell wall biosynthesis [33]. The induction pattern of the VraSR-regulated genes was very similar to that observed with vancomycin-treated cells in another transcription profiling study with another S. aureus strain, N315 [33]. In addition to the effects on membranes, several antimicrobial peptides such as nisin, mersacidin and bacitracin inhibit cell wall biosynthesis [41,43-45]. Whether the VraSR-inducing linear CAMPs used in this study inhibit cell wall biosynthesis and cause a cell wall defect cannot be judged from our data, but this is the most likely explanation for the similar induction patterns of the VraSR-regulated genes. A transcription profiling study with a lipopeptide antibiotic daptomycin also showed up-regulation of the the VraSR cell wall regulon [46], which is probably caused by an inhibitory effect on the cell wall biosynthesis [47], although the results furthermore suggested that some of the up-regulated genes in the daptomycin transcriptome were induced by its membrane depolarization effect [46]. A similar dual effect has also been shown with human $\beta$-defensin 3 [48].

In $B$. subtilis, the $\gamma x d L M$ operon, which encodes an $A B C$ transporter, is strongly induced by human cathelicidin LL37 in a manner dependent on the YxdJK two-component system, but not at all by porcine protegrin PG-1 and a model antimicrobial peptide poly-L-lysine [25]. This indicates that antimicrobial peptides can be very specific in activating stress sensors and the activation mechanism 
A

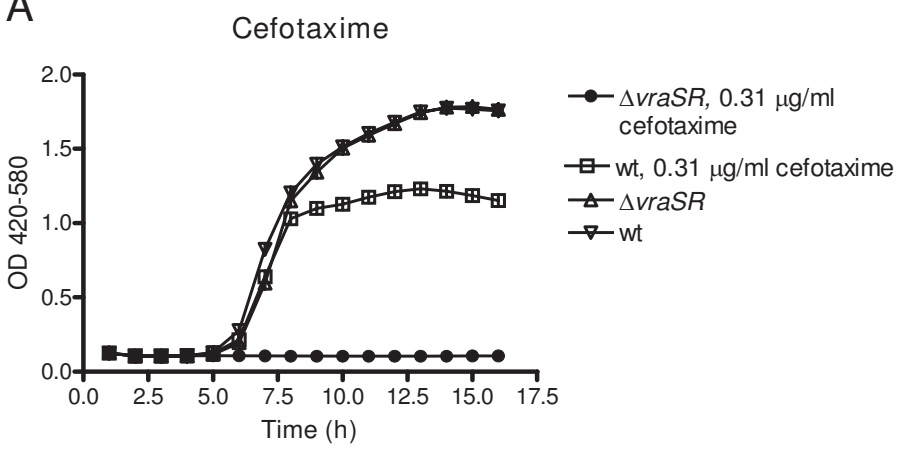

B

EGTA

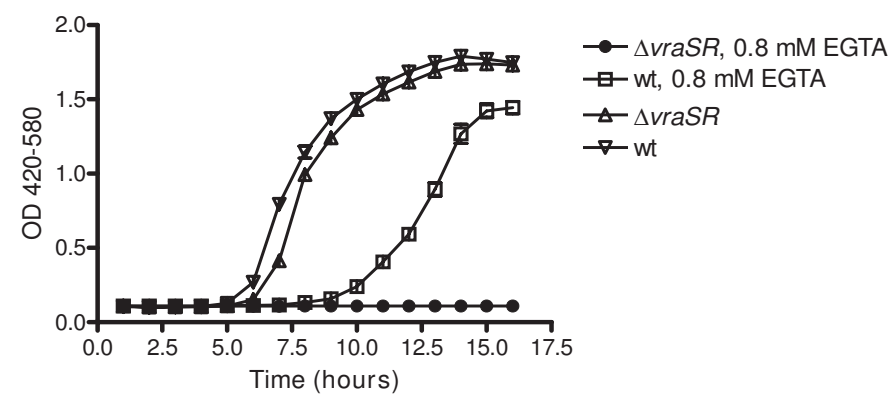

C

Chlorpromazine

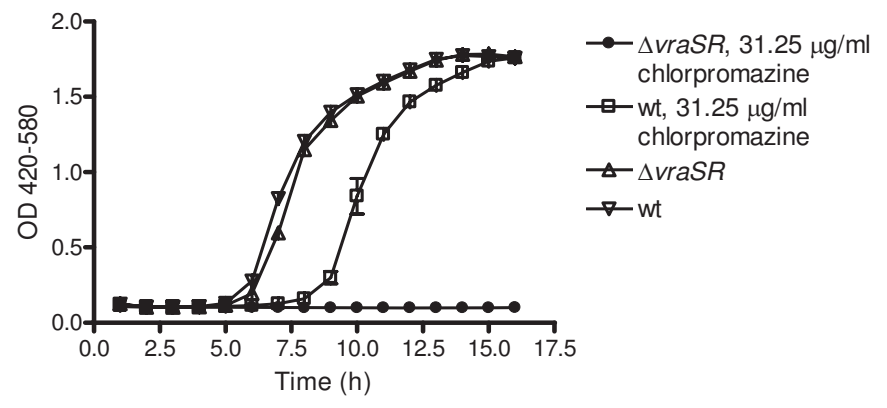

D Sodium tungstate

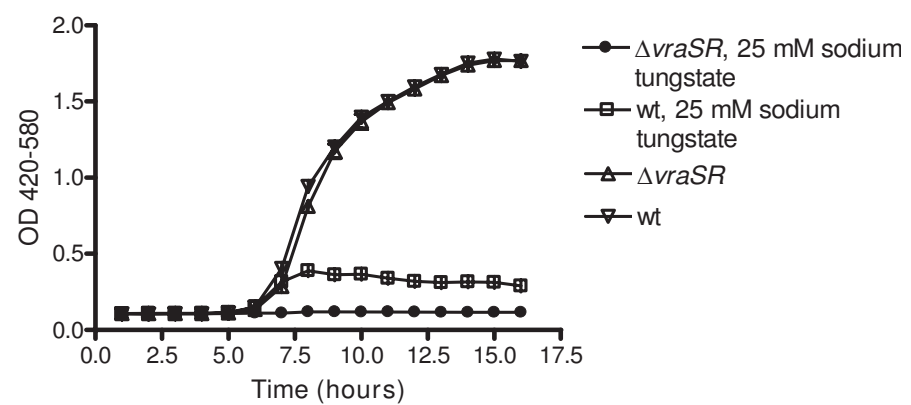

\section{Figure 2}

Increased sensitivity of the $\triangle v$ raRS mutant to cefotaxime, EGTA, chlorpromazine and sodium tungstate. The $\Delta v r a R S$ mutant and the wild-type $S$. aureus Newman strain were grown either in the presence or absence of the antimicrobial agents as indicated in $150 \mu \mathrm{l}$ of BHI medium in wells of microtiter plates in a Bioscreen for 16 hours. The optical densities of the cultures were measured every 15 minutes. The data points show the densities measured at one-hour intervals. 
may even be dependent on the mode of action, charge or structural properties of the peptides. In this study we found that the vraDE ones were the most strongly induced genes in cells treated with ovispirin-1- $\mathrm{NH}_{2}$ or dermaseptin K4-S4(1-16)- $\mathrm{NH}_{2}$. We could demonstrate that the high level of induction of vraDE with ovispirin-1- $\mathrm{NH}_{2}$ was dependent on the amide group at the $\mathrm{C}$-terminus. The antimicrobial effects of these two variants of ovispirin-1 on wild-type $S$. aureus Newman strain were not different. The expression regulation of $v \mathrm{raDE}$ is under the control of the Aps (GraRS) sensor system, which also controls the expression of $v r a F G$, encoding a putative peptide efflux pump, dlt operon, encoding components responsible for the D-alanylation of teichoic acids and modulation of the net negative charge of the cell wall, and $m p r F$, encoding the MprF enzyme which catalyzes the lysinylation of phosphatidylglycerol and modulates the charge of the outer surface of the cell membrane [37]. It has been shown that a nine-aminoacid loop of the ApsS sensor exposed on the outer surface of the membrane interacts with CAMPs when activating the sensor [37]. Our results suggest that in linear peptides the C-terminal amide group is an important element for the activation of the ApsS sensor. In the study by Li and collaborators [37] the peptides which naturally contain an amide group at the C-terminus, indolicidin and melittin, were significantly better inducers of the dltB gene than those that do not have the amide such as magainin II and nisin. The vraDE genes were also the most strongly induced genes in the stress response to C-terminally amide-modified human cathelicidin LL-37 (our unpublished results). However, the low level of induction of $v \mathrm{raDE}$ with temporin $\mathrm{L}-\mathrm{NH}_{2}$ in this study suggests that the C-terminal amide is not the only element that is recognized by the ApsS sensor and needed for the induction. Alternatively, the level of the induction of the Aps regulon might rather depend on the absence of the carboxyl group than on the presence of the amide. Mersacidin, which is a lantibiotic, but unlike nisin, does not have a free C-terminal carboxyl group due to an intramolecular thioether-ethyleneamide bridge, is a very strong inducer of vraDE [49] and might fit this model.

VraDE is a transporter system that is dedicated to resist bacitracin, as evidenced in this study by the testing the sensitivity of the vraDE null mutant(s) to 11 antimicrobial peptides or antibiotics and numerous other antimicrobial agents (PM analysis). The $\triangle v r a D E$ mutant(s) was more susceptible to bacitracin but not to any other antimicrobial tested. Consistently, VraDE is similar to the BceAB bacitracin transport system of $B$. subtilis $[34,35]$ and probably comprise together with VraFG an efflux pump system for combating bacitracin [37]. A recent study suggested that in B. subtilis bacitracin sensing and the expression of the $b c e A B$ genes are dependent on active bacitracin transport via $\mathrm{Bce} A \mathrm{~B}$ and that the large periplasmic loop of the
BceA permease component of the transporter may be involved in mediating the signal to the BceRS two-component system [50]. We found that bacitracin is a strong inducer of vraDE expression. Whether the sensing mechanism of Aps is dependent on the transport function of VraDE or VraFG, whether Aps senses linear CAMPs and bacitracin in a similar manner and whether the amide group of the side chain of glutamine in the cyclic bacitracin peptide [51] have a similar essential role in the activation, should be addressed in future studies. The $\mathrm{C}$ terminal amide being in a sequence contex that is appropriate for the interaction with the sensory loop of ApsS most probably explains the differences in the induction patterns of the vraDE, vraF and dltA genes observed in this study. However, we can not rule out the possibility that the carpet-mode of action mechanism influences the induction, since the amide-modified carpet peptides ovispirin-1- $\mathrm{NH}_{2}$ and dermaseptin $\mathrm{K} 4-\mathrm{S} 4(1-16)-\mathrm{NH}_{2}$ were clearly stronger inducers of these genes than the amidemodified toroidal pore-forming peptide temporin $\mathrm{L}-\mathrm{NH}_{2}$.

In addition to vraDE, SA0205 was strongly induced by CAMPs, but in this case the strongest inducer was temporin $\mathrm{L}_{-} \mathrm{NH}_{2}$. Our results indicated that SA0205, which encodes a putative cell membrane-associated peptidase, belongs to the VraSR regulon. The over 100-fold induced (qRT-PCR) SAS016 encodes a small protein with unknown function and mechanism of regulation. It was also strongly induced by vancomycin [52], suggesting that it responds to a cell wall defect. Furthermore, it was detected at both transcript and protein levels in GISA strains [53]. S. aureus cells try to adapt to the stress and harmful effects of CAMPs by inducing or repressing several gene systems. These responses include the induction of the ctsR, dnaJ, dnaK, hrcA, groEL and groES general stress genes and genes resisting oxidative stress (katA, $\operatorname{tr} x B$ and SA2324). Some of these targets showed similar inductions in $S$. aureus during phagocytosis by neutrophils or when surviving within epithelial and phagocytic cells $[54,55]$. Notably, several amino acid biosynthesis operons and genes encoding enzymes of the citric acid cycle were also induced and genes involved in anaerobic metabolism were repressed, indicating that the cells were metabolically active and respiring aerobically. The down-regulation of virulence gene expression is partly caused by the repression of saeRS, but also the decreased expression of the agr operon affects their low expression.

S. aureus is a human pathogen and it can be argued that the CAMPs of animal origin may cause a different kind of transcriptional response than CAMPs of the natural host. A transcriptional analysis of responses of $S$. aureus (SG511) to human $\beta$-defensin 3 (hBD3) showed that vraDE, vraSR and SA0205 were also induced by this human CAMP [48], as was the case with the animal 
CAMPs in this study. The most notable difference in the transcriptomes is the very strong induction of the SA0192 gene, which encodes a protein similar to $\mathrm{ABC}$ transporter ATP-binding proteins, in SG511 cells exposed to hBD3. Since this gene is absent in the genome of the $S$. aureus Newman strain, it is not among the induced genes of this study. Sass and collaborators recently showed that a knockout mutation of $v \mathrm{raE}$ increases the susceptibility of S. aureus SG511 also to other antibiotics than bacitracin, including antimicrobial peptides hBD3, LL-37, Pep5 and nisin [48]. The defective GraRS/Aps sensory system of the strain SG511 [56] may explain the inconsistency with the result of this study.

The $\Delta$ vraSR mutant exhibited enhanced sensitivity to several antimicrobial agents as compared to the wild-type strains. They were more sensitive to the amide-modified ovispirin-1 but not to the non-modified one. Ovispirin-1$\mathrm{NH}_{2}$ was a better activator of Aps and VraSR than ovispirin-1 and this may explain the higher resistance of the wild-type strain to the amide-modified peptide. The $\Delta v r a S R$ mutation also decreased the MIC values of bacitracin and teicoplanin. This effect is similar to what has been observed with a $\Delta v$ raSR mutant of S. aureus N315 [33]. Our phenotype microarray analysis revealed increased sensitivity of the $S$. aureus Newman $\triangle v r a S R$ mutant to a wide range of $\beta$-lactam antibiotics. Furthermore, we showed that $\Delta v r a S R$ increased susceptibility to other types of antimicrobial agents such as EGTA and phenothiazines. Since EGTA is a metal-chelator, it probably harmfully affects bacterial cells and particularly severely $\Delta v r a S R$ mutant cell by binding to divalent metal cations in the cell wall and consequently causing metal sequestration. The phenothiazines chlorpromazine and thioridazine, which are or have been used in psychiatric therapy, are potential lead compounds for the development of new cell wall-active antibiotics. It has been shown that the dosage of chlorpromazine used in psychiatry results in intracellular concentrations of this drug that are antimicrobial [57].

\section{Conclusion}

The current rapid increase in antibiotic resistance among human pathogens coincides dangerously with a lack of novel antibiotic discovery. A promising alternative is a class of short peptides known as antimicrobial peptides, or host defense peptides, which are found among all classes of life but have yet to be widely exploited for pharmaceutical purposes. In order to identify the inducible resistance mechanism of Staphylococcus aureus against antimicrobial peptides and other antimicrobial agents, the bacterium was exposed to antimicrobial peptides and gene expression changes were analyzed. The analysis revealed similar gene induction patterns with cell wallactive antibiotics but also some distinctly different ones. The induction of the VraSR regulon suggests that antimi- crobial peptides have an inhibitory effect on the cell wall biosynthesis. This must be verified biochemically in future studies. Parts of the signalling pathways are not specifically dedicated to CAMP defense but are regulated following the lifestyle of pathogenic bacteria which are potentially exposed to a wide diversity of environmental changes.

This study does not provide a definitive answer as to whether the mode of action of CAMPs on lipid bylayers is responsible for certain induction patterns, but this is a potential alternative. For instance in the case of the induction of the SA1217-SA1221 operon, the carpet-forming peptides ovispirin-1- $\mathrm{NH}_{2}$ or dermaseptin K4-S4(1-16)$\mathrm{NH}_{2}$ were strong inducers whereas the pore-forming peptide temporin $\mathrm{L}-\mathrm{NH}_{2}$ was unable to induce this operon. Most importantly, it was found that modifying the carboxy-terminus of a linear peptide with an amide group can modulate drastically its properties as an inducer of resistance mechanisms. This result may allow the rational design of antimicrobial agents that lack the properties to induce resistance mechanisms. Inactivating the VraSR cell wall stress management system increased susceptibility of the bacterium to a wide range of cell wall-active antibiotics but also susceptibility to several non-antibiotic antimicrobials was increased. Particularly interesting in the latter group are the established antipsychotic drugs, chlorpromazine and thioridazine, which are potential lead molecules for developing novel antibiotics.

\section{Methods}

\section{Bacterial strains, plasmids and growth conditions}

The bacterial strains and plasmids used are listed in Table 5. E. coli cells were grown in Luria-Bertani (LB) broth supplemented with ampicillin $\left(100 \mu \mathrm{g} \mathrm{ml}^{-1}\right)$ and $S$. aureus cells in BHI (Brain Heart Infusion) and TSB (Tryptone Soya Broth) media supplemented with chloramphenicol $\left(10 \mu \mathrm{g} \mathrm{ml}^{-1}\right)$ and/or erythromycin $\left(2.5 \mu \mathrm{g} \mathrm{ml}^{-1}\right)$ when needed. To determine the subinhibitory concentrations of temporin L-NH ${ }_{2}$ (FVQWFSKFLGRIL- $\mathrm{NH}_{2}$ ) ovispirin-1$\mathrm{NH}_{2}\left(\right.$ KNLRRIIRKIIHIIKKYG-NH $\left.{ }_{2}\right)$ and dermaseptin K4$\mathrm{S} 4(1-16)-\mathrm{NH}_{2}$ (ALWKTLLKKVLKAAAK-NH $\left.{ }_{2}\right), 150 \mu \mathrm{l}$ of BHI medium was inoculated with approximately $10^{5} \mathrm{~S}$. aureus Newman cells in honeycomb 2 plate wells, peptides were added in two-fold dilution series, and the cultures were incubated with continuous and moderate shaking at $37^{\circ} \mathrm{C}$ and culture densities were measured in a Bioscreen C Microbiology reader (Growth Curves, Helsinki, Finland). The peptide treatments for the gene expression analyses were carried out in the exponential growth phase $\left(\sim \mathrm{OD}_{560}=0.6\right)$; CAMPs were added at the final (sublethal) concentrations of $3 \mu \mathrm{M}$ (temporin L$\mathrm{NH}_{2}$ ), $4 \mu \mathrm{M}$ (ovispirin-1- $\mathrm{NH}_{2}$ ) and $3 \mu \mathrm{M}$ (dermaseptin K4-S4(1-16)- $\mathrm{NH}_{2}$ ) if not otherwise indicated. The addition of the peptides at these sublethal concentrations slowed down the growth slightly. The peptides were pur- 
chased from EZbiolab (Carmel, IN, USA) and their purity was 95\%. The Minimal Inhibitory Concentration (MIC) determinations were performed by cultivating $S$. aureus Newman or RN4220 cells and their vraSR and/or vraDE null mutation derivatives in $100 \%$ (temporin $\mathrm{L}^{-\mathrm{NH}_{2}}$, ovispirin-1- $\mathrm{NH}_{2}$, ovispirin-1, nisin, vancomycin, bacitracin, teicoplanin, daptomycin and pentaglysine), 50\% (LL-37, nisin and Pep5) or 25\% (hBD3) Mueller-Hinton broth for 16-24 hours. Typically, an overnight grown culture was diluted $1 / 10000$ and $1 \mathrm{ml}$ of broth in a $15 \mathrm{ml}$ sterile Falcon tube was inoculated with $10 \mu \mathrm{l}$ of the diluted culture and cultivated at $37^{\circ} \mathrm{C}$ with shaking $(220$ $\mathrm{rpm} \min ^{-1}$ ). Each MIC determination was performed twice with a two-fold dilution series of the antimicrobial agents.

\section{Isolation of total cellular RNA}

The samples for RNA isolations were taken 10 minutes after the addition of the antimicrobial peptides or other antimicrobial agents at the cell density of $\mathrm{OD}_{600}=0.6$ or Klett 50. The cells from $1.8-2 \mathrm{ml}$ of the cultures (BHI medium) were harvested by centrifugation. The supernatants were discarded and the bacterial pellets were frozen in liquid nitrogen if the RNA isolation was not conducted immediately. The control samples without peptides were treated in a similar manner. The cell pellets were resuspended in $200 \mu \mathrm{l} \mathrm{TE}-$ buffer ( $10 \mathrm{mM}$ Tris-HCl, $1 \mathrm{mM}$ EDTA $\mathrm{pH} 7.0)$ containing lysostaphin $\left(125 \mu \mathrm{g} \mathrm{ml}^{-1}\right)$ and incubated at $37^{\circ} \mathrm{C}$ for 10 minutes. RNA was extracted by using Roche's High Pure RNA Isolation Kit according to the manufacturer's instructions.

\section{Transcriptional analysis by oligo DNA microarray}

The effects of the three different antimicrobial peptides on gene expression of $S$. aureus Newman were studied by using whole genome oligo-DNA microarrays. Bacteria were grown in BHI medium to the early exponential phase $\left(\mathrm{OD}_{600}=0.6\right)$ and antimicrobial peptides were added at the sublethal concentrations described above. Samples were taken for RNA isolations after treating the cultures with the peptides for 10 minutes. Control cultures without peptide additions were treated similarly and in parallel. Genes with at least 2-fold induction/reduction of expression in the peptide-treated cells as compared to the control cells (non-treated) were accepted as differentially expressed genes.

The microarray was manufactured by in situ synthesis of 10'807, 60-mer oligonucleotide probes (Agilent, Palo Alto, CA, USA), selected as previously described [38]. It covers $>98 \%$ of all ORFs annotated in strains N315 and Mu50 [58], MW2 [59] COL [60], NCTC8325 (the sequence, locus NC_007795, can be found at the National Center for Biotechnology Information [61]), USA300 [62], MRSA252 and MSSA476 [63] including their respective plasmids. Extensive experimental validation of this array has been described previously, using CGH (comparative genomic hybridization), mapping of deletion, specific PCR and quantitative RT-PCR $[38,64]$.

Total RNA was further purified with Qiagen RNeasy mini kit and treated with DNAse following the manufacturer's recommendations. The absence of remaining DNA traces was evaluated by quantitative PCR (SDS 7700; Applied Biosystems, Framing-ham, MA) with assays specific for 16 s rRNA $[53,65]$. Samples of $8 \mu \mathrm{g}$ total $S$. aureus RNA were labelled by Cy-3 or Cy- 5 dCTP using the SuperScript II (Invitrogen, Basel, Switzerland) following the manufacturer's instructions. Labelled products were then purified with QiaQuick columns (Qiagen). A mixture of control (without peptide) and test conditions (with peptide) was then diluted in $250 \mu \mathrm{l}$ Agilent hybridization buffer, and

Table 5: Bacterial strains and plasmids.

\begin{tabular}{|c|c|c|}
\hline Strain/Plasmid & Description & Reference/Origin \\
\hline \multicolumn{3}{|l|}{ E. coli } \\
\hline 5-alpha & cloning strain & New England Biolabs \\
\hline \multicolumn{3}{|l|}{ S. aureus } \\
\hline Newman & ATCC25904, methicillin susceptible & {$[72]$} \\
\hline RN4220 & NCTC 8325-4-r, restriction negative strain & {$[73]$} \\
\hline COL & methicillin resistant (MRSA) & {$[60]$} \\
\hline $\mathrm{RH} 7657$ & Newman $\Delta v r a S R:: e r y$ & this study \\
\hline RH766I & Newman $\Delta v r a D E:: e r y$ & this study \\
\hline RH7788 & RN4220 $\Delta v r a D E:: e r y$ & this study \\
\hline RH7790 & RN4220 $\Delta v r a S R:: e r y$ & this study \\
\hline \multicolumn{3}{|l|}{ Plasmids } \\
\hline pGEM-3zf(+) & cloning vector, $\mathrm{amp}^{\mathrm{r}}(E$. coli $)$ & Promega \\
\hline PKORI & gene replacement vector, ampr $(E$. coli), chlr (S. aureus) & {$[69]$} \\
\hline pKTH3762 & pGEM-3zf(+) containing the vraSR deletion cassette, amp ${ }^{r}(E$. coli) & this study \\
\hline pKTH3763 & pKORI containing the vraSR deletion cassette, $\operatorname{amp}^{r}$ (E. coli), chlr ery ${ }^{r}$ (S. aureus) & this study \\
\hline pKTH3764 & pGEM-3zf(+) containing the vraDE deletion cassette, amp ${ }^{r}(E$. coli) & this study \\
\hline pKTH3765 & pKORI containing the vraDE deletion cassette, amp ${ }^{r}\left(E\right.$. coli), chlr ${ }^{r}$ ery $^{r}$ (S. aureus) & this study \\
\hline
\end{tabular}


hybridized at a temperature of $60^{\circ} \mathrm{C}$ for 17 hours in a dedicated hybridization oven (Robbins Scientific, Sunnyvale, CA, USA). The slides were washed with Agilent proprietary buffers, dried under a nitrogen flow, and scanned (Agilent, Palo Alto, CA, USA) using 100\% PMT (photomultiplier tube) power for both wavelengths.

Fluorescence intensities were extracted using the Feature extraction $^{\mathrm{TM}}$ software (Agilent, version 8). Local background-subtracted signals were corrected for unequal dye incorporation or unequal load of labelled product. The algorithm consisted of a rank consistency filter and a curve fit using the default LOWESS (locally weighted linear regression) method. Data consisting of three independent biological experiments were analyzed using GeneSpring 7.3 (Agilent) after per gene and per chip normalization. The statistical significance of differentially expressed genes was identified by variance analysis (ANOVA) [53,66], performed using GeneSpring, including the Benjamini and Hochberg false discovery rate correction $(5 \%)$. Genes showing significant changes $(\mathrm{P}<$ 0.05 ) and at least a 2-fold induction/reduction of expression, in the peptide-treated cells as compared to the control cells (non-treated) were accepted as differentially expressed.

\section{Quantitative real-time RT-PCR}

cDNA was synthesized with $1 \mu \mathrm{g}$ of total cellular RNA by using a High Capacity cDNA Archive Kit (Applied Biosystems) with an additional step of DNase I (Roche) treatment [67] The quantitative real-time PCR was performed as previously described [25] by using specific primer pairs and a SYBR Green PCR system kit (Applied Biosystems). The primers (additional file 6) were purchased from TAG Copenhagen. The amplification reactions and detection of PCR products were performed with a 7500 real time PCR system (Applied Biosystems). The cDNA values were normalized with the value of gyrA.

\section{Construction of the vraDE and vraSR null mutants}

In order to construct null mutants of the vraDE and vraSR operons, about $1 \mathrm{~kb}$ DNA fragments of both the upstream and downstream regions of the target operons were PCR amplified. The template DNA was $S$. aureus chromosome either from the strain Newman (vraSR) or COL (vraDE). The primers used in the PCR reactions are shown in additional file 6. The upstream fragments digested with PstI and SalI and the downstream fragments digested with BamHI and EcoRI/SacI were ligated with a PCR-amplified DNA fragment containing the erythromycin resistance gene of pMUTIN4 [68]. The resulting vraDE and vraSR inactivation cassettes were inserted into the pGEM3Zf $(+)$ plasmid vector between the PstI and EcoRI/SacI sites, followed by transformation of competent E. coli 5-alpha (NEB) cells with the ligated DNA. The inactivation cas- settes were then PCR amplified by using the pGEM3Zf(+) constructs as PCR templates and specific oligonucleotides, containing the sequences of attB1 and attB2 sites, as PCR primers. The amplified fragments were inserted into the pKOR1 gene replacement plasmid in a recombination reaction with Clonase (Invitrogen) as previously described [69]. The resulting pKOR1-inactivation cassette constructs were used to transform electrocompetent $S$. aureus RN4220 cells by electroporation [70] and transformants were selected by cultivating them on BHI agar plates supplemented with chloramphenicol $\left(10 \mu \mathrm{g} \mathrm{ml}^{-1}\right)$ and erythromycin $\left(2.5 \mu \mathrm{g} \mathrm{ml}^{-1}\right)$ at $30^{\circ} \mathrm{C}$. The gene replacement plasmids were isolated from the RN4220 transformants and subsequently electroporated into $S$. aureus Newman cells. The mutant construction was performed as described [69]. Briefly, S. aureus Newman or RN4220 cells harbouring the gene replacement plasmids were cultivated in TSB medium overnight at $43^{\circ} \mathrm{C}$, a non-permissive temperature for the replication of pKOR1 and its derivative plasmids, to force the plasmids to integrate into the chromosome by a Campbell-type recombination at a flanking region of the target gene. The resulting merodiploid cells were cultivated on TSA plates containing $100 \mathrm{ng}$ $\mathrm{ml}^{-1}$ anhydrotetracyclin but not chloramphenicol to induce pKOR1-encoded secY antisense transcripts and counter-select cells which via homologous recombination between the gene duplicates had lost the pKOR1. The presence of erythromycin $\left(2.5 \mu \mathrm{g} \mathrm{ml}^{-1}\right)$ on the plates allowed the selection of the mutants. The mutants were verified by PCR with appropriate primers (additional file 6).

\section{Phenotype microarray (PM) analysis of the vraDE and vraSR null mutants}

The PM analysis was carried out by using the service of Biolog (Hayward, CA, USA). We wanted to identify antimicrobial agents and stress conditions which are more harmful to the mutant cells than the wild-type $S$. aureus Newman cells. Therefore, the analysis was performed only with sensitivity panels 11-20, which allowed the testing of 960 stress conditions and 240 different antimicrobial agents on ten 96-well plates. The method has been described more thoroughly in a previous study [71]. Briefly, the growth of bacteria in a well of the PM panels can be quantitated since growing, metabolically-active bacteria reduce the tetrazolium indicator dye and blue color is formed. Bacteria were grown in BHI medium for 24 hours in an OmniLog instrument. The color changes of the redox dye in the cultures were compared (mutant versus wild type). The formation of the reduced tetrazolium was recorded either as a green tracing (mutant) or a red tracing (wild-type strain). The OmniLog PM bioinformatics software was used to overlay the color-coded images of the kinetics of the tetrazolium reduction and compare and quantify them. Each strain was analyzed twice and con- 
sensus images were obtained showing the differences in antimicrobial sensitivity that were detected in both PM runs.

\section{Authors' contributions}

Experimental planning: VPK. Performed DNA microarrays and data analysis: PF JS MP VPK. Performed qRT-PCR measurements: MP HLH. Constructed mutants: MP VPK. Performed antimicrobial sensitivity measurements: MP VPK VS HGS. Wrote the paper: MP PF VPK.

\section{Additional material}

\section{Additional file 1}

Genes and operons induced by several cationic antimicrobial peptides. The table shows the genes induced at least 2-fold by several cationic antimicrobial peptides.

Click here for file

[http://www.biomedcentral.com/content/supplementary/14712164-10-429-S1.doc]

\section{Additional file 2}

Genes and operons down-regulated by several cationic antimicrobial peptides. The table shows the genes down-regulated by several cationic antimicrobial peptides.

Click here for file

[http://www.biomedcentral.com/content/supplementary/1471-

2164-10-429-S2.doc]

\section{Additional file 3}

Antimicrobial sensitivity of S. aureus RN4220 and its $\triangle \mathrm{vraDE}$ and $\triangle \mathrm{vraSR}$ mutant derivatives. The table shows MIC values of antimicrobial peptides and other antimicrobial agents against S. aureus RN4220 and its $\Delta \mathrm{vraDE}$ and $\Delta \mathrm{vraSR}$ mutant derivatives.

Click here for file

[http://www.biomedcentral.com/content/supplementary/1471-

2164-10-429-S3.doc]

\section{Additional file 4}

Antimicrobial sensitivities of RH7657 (vraSR::ery) and RH7603 (S. aureus Newman) were compared by using phenotype microarrays. Scatter plots of parameter values from two replicates of the PM analysis are shown in the two uppermost panels. The three other panels show overlaid color-coded images of tetrazolium reduction kinetics (mutant versus wild type) over all wells in the two runs of the analysis and their consensus.

Click here for file

[http://www.biomedcentral.com/content/supplementary/14712164-10-429-S4.doc]

\section{Additional file 5}

Decreased reduction of tetrazolium in vraSR null mutant treated with antimicrobial agents as compared to the wild-type S. aureus Newman strain. The gene list was obtained from the consensus of the two independent phenotype microarray analyses shown in additional file 4.

Click here for file

[http://www.biomedcentral.com/content/supplementary/14712164-10-429-S5.doc]

\section{Additional file 6}

Specific primer pairs for qRT-PCR and PCR. The table shows the primers used in this study.

Click here for file

[http://www.biomedcentral.com/content/supplementary/14712164-10-429-S6.doc]

\section{Acknowledgements}

This work was supported by grants 107438, II 3846 and 1233 I 8 from the Academy of Finland (VPK, MP and HLH), by grants 404940-106296/I and 3100A0-II6075/I (PF), PP00B--103002/I and 3100A0-II2370/I (JS) from the Swiss National Science Foundation as well as by grant GFKIII I 3506 from the German Ministry of Education and Research (BMBF) (HGS and VS).

We thank Dr Taeok Bae, University of Chicago, for the plasmid pKORI.

\section{References}

I. Brogden KA: Antimicrobial peptides: pore formers or metabolic inhibitors in bacteria? Nat Rev Microbiol 2005, 3(3):238-250.

2. Hancock RE, Diamond G: The role of cationic antimicrobial peptides in innate host defences. Trends Microbiol 2000, 8(9):402-410.

3. Peschel A, Sahl HG: The co-evolution of host cationic antimicrobial peptides and microbial resistance. Nat Rev Microbio 2006, 4(7):529-536.

4. Yeaman MR, Yount NY: Mechanisms of antimicrobial peptide action and resistance. Pharmacol Rev 2003, 55(I):27-55.

5. Yang L, Harroun TA, Weiss TM, Ding L, Huang HW: Barrel-stave model or toroidal model? A case study on melittin pores. Biophys J 200 I, 8 I (3): I 475- I 485.

6. Shai $Y$, Oren Z: From "carpet" mechanism to de-novo designed diastereomeric cell-selective antimicrobial peptides. Peptides 200I, 22(10):1629-I64I.

7. Rosenfeld Y, Barra D, Simmaco M, Shai Y, Mangoni ML: A synergism between temporins toward Gram-negative bacteria overcomes resistance imposed by the lipopolysaccharide protective layer. J Biol Chem 2006, 28 I (39):28565-28574.

8. Peschel A, Jack RW, Otto M, Collins LV, Staubitz P, Nicholson G, Kalbacher H, Nieuwenhuizen WF, Jung G, Tarkowski A, et al: Staphylococcus aureus resistance to human defensins and evasion of neutrophil killing via the novel virulence factor MprF is based on modification of membrane lipids with I-lysine. J Exp Med 200I, 193(9):1067-1076.

9. Peschel A, Otto M, Jack RW, Kalbacher H, Jung G, Götz F: Inactivation of the dlt operon in Staphylococcus aureus confers sensitivity to defensins, protegrins and other antimicrobial peptides. J Biol Chem 1999, 274:8405-84I0.

10. Abachin E, Poyart C, Pellegrini E, Milohanic E, Fiedler F, Berche P, Trieu-Cuot P: Formation of D-alanyl-lipoteichoic acid is required for adhesion and virulence of Listeria monocytogenes . Mol Microbiol 2002, 43(I): I-I4.

II. Kristian SA, Datta V, Weidenmaier C, Kansal R, Fedtke I, Peschel A Gallo RL, Nizet V: D-alanylation of teichoic acids promotes group a streptococcus antimicrobial peptide resistance, neutrophil survival, and epithelial cell invasion. J Bacteriol 2005, 187(19):67| 19-6725.

12. Kristian SA, Durr M, Van Strijp JA, Neumeister B, Peschel A: MprFmediated lysinylation of phospholipids in Staphylococcus aureus leads to protection against oxygen-independent neutrophil killing. Infect Immun 2003, 7 I(I):546-549.

13. Poyart C, Pellegrini E, Marceau M, Baptista M, Jaubert F, Lamy MC, Trieu-Cuot P: Attenuated virulence of Streptococcus agalactiae deficient in D-alanyl-lipoteichoic acid is due to an increased susceptibility to defensins and phagocytic cells. Mol Microbiol 2003, 49(6): $1615-1625$. 
14. Boll M, Radziejewska-Lebrecht J, Warth C, Krajewska-Pietrasik D, Mayer H: 4-Amino-4-deoxy-L-arabinose in LPS of enterobacterial R-mutants and its possible role for their polymyxin reactivity. FEMS Immunol Med Microbiol I994, 8(4):329-34I.

15. Helander IM, Kilpeläinen I, Vaara M: Increased substitution of phosphate groups in lipopolysaccharides and lipid $A$ of the polymyxin-resistant pmrA mutants of Salmonella typhimurium: a 3 I P-NMR study. Mol Microbiol I994, I I (3):48 I-487.

16. Nummila K, Kilpeläinen I, Zahringer U, Vaara M, Helander IM: Lipopolysaccharides of polymyxin B-resistant mutants of Escherichia coli are extensively substituted by 2-aminoethyl pyrophosphate and contain aminoarabinose in lipid A. Mol Microbiol 1995, I6(2):27I-278.

17. Tran AX, Lester ME, Stead CM, Raetz CR, Maskell DJ, McGrath SC, Cotter RJ, Trent MS: Resistance to the antimicrobial peptide polymyxin requires myristoylation of Escherichia coli and Salmonella typhimurium lipid A. J Biol Chem 2005, 280(3I):28I86-28I94.

18. Zhou Z, Ribeiro AA, Lin S, Cotter RJ, Miller SI, Raetz CR: Lipid A modifications in polymyxin-resistant Salmonella typhimurium: PMRA-dependent 4-amino-4-deoxy-L-arabinose, and phosphoethanolamine incorporation. J Biol Chem 200I, 276(46):43III-43I2I.

19. Sieprawska-Lupa M, Mydel P, Krawczyk K, Wojcik K, Puklo M, Lupa B, Suder P, Silberring J, Reed M, Pohl J, et al.: Degradation of human antimicrobial peptide LL-37 by Staphylococcus aureus -derived proteinases. Antimicrob Agents Chemother 2004, 48( I 2):4673-4679.

20. Thwaite JE, Hibbs S, Titball RW, Atkins TP: Proteolytic degradation of human antimicrobial peptide LL-37 by Bacillus anthracis may contribute to virulence. Antimicrob Agents Chemother 2006, 50(7):2316-2322.

21. Jin T, Bokarewa M, Foster T, Mitchell J, Higgins J, Tarkowski A: Staphylococcus aureus resists human defensins by production of staphylokinase, a novel bacterial evasion mechanism. J Immunol 2004, I72(2): I I69-1 I76.

22. Shafer WM, Qu X, Waring AJ, Lehrer RI: Modulation of Neisseria gonorrhoeae susceptibility to vertebrate antibacterial peptides due to a member of the resistance/nodulation/division efflux pump family. Proc Natl Acad Sci USA 1998, 95(4): I829-I833.

23. Tzeng YL, Ambrose KD, Zughaier S, Zhou X, Miller YK, Shafer WM, Stephens DS: Cationic antimicrobial peptide resistance in Neisseria meningitidis. J Bacteriol 2005, I 87( I 5):5387-5396.

24. Bader MW, Sanowar S, Daley ME, Schneider AR, Cho U, Xu W, Klevit RE, Le Moual H, Miller SI: Recognition of antimicrobial peptides by a bacterial sensor kinase. Cell 2005, I 22(3):46 I-472.

25. Pietiäinen M, Gardemeister M, Mecklin M, Leskelä S, Sarvas M, Kontinen VP: Cationic antimicrobial peptides elicit a complex stress response in Bacillus subtilis that involves ECF-type sigma factors and two-component signal transduction systems. Microbiology 2005, I 5 I(Pt 5): I577-I592.

26. Amiche $M$, Seon AA, Pierre TN, Nicolas P: The dermaseptin precursors: a protein family with a common preproregion and a variable C-terminal antimicrobial domain. FEBS Lett 1999 , 456(3):352-356

27. Simmaco M, Mignogna G, Canofeni S, Miele R, Mangoni ML, Barra D: Temporins, antimicrobial peptides from the European red frog Rana temporaria. Eur J Biochem 1996, 242(3):788-792.

28. Sawai MV, Waring AJ, Kearney WR, McCray PB Jr, Forsyth WR, Lehrer RI, Tack BF: Impact of single-residue mutations on the structure and function of ovispirin/novispirin antimicrobial peptides. Protein Eng 2002, I 5(3):225-232.

29. Navon-Venezia S, Feder R, Gaidukov L, Carmeli Y, Mor A: Antibacterial properties of dermaseptin $\mathrm{S} 4$ derivatives with in vivo activity. Antimicrob Agents Chemother 2002, 46(3):689-694.

30. Rinaldi AC, Mangoni ML, Rufo A, Luzi C, Barra D, Zhao H, Kinnunen PK, Bozzi A, Di Giulio A, Simmaco M: Temporin L: antimicrobial, haemolytic and cytotoxic activities, and effects on membrane permeabilization in lipid vesicles. Biochem J 2002, 368(Pt I): $91-100$

31. Zhao $\mathrm{H}$, Kinnunen PK: Binding of the antimicrobial peptide temporin $L$ to liposomes assessed by Trp fluorescence. J Biol Chem 2002, 277(28):25170-25177.

32. Gene Expression Omnibus [http://www.ncbi.nlm.nih.gov/geo/]

33. Kuroda M, Kuroda H, Oshima T, Takeuchi F, Mori H, Hiramatsu K: Two-component system VraSR positively modulates the regulation of cell-wall biosynthesis pathway in Staphylococcus aureus. Mol Microbiol 2003, 49(3):807-82I.

34. Mascher T, Margulis NG, Wang T, Ye RW, Helmann JD: Cell wall stress responses in Bacillus subtilis: the regulatory network of the bacitracin stimulon. Mol Microbiol 2003, 50(5): I59|-I604.

35. Ohki R, Giyanto , Tateno K, Masuyama W, Moriya S, Kobayashi K, Ogasawara N: The BceRS two-component regulatory system induces expression of the bacitracin transporter, BceAB, in Bacillus subtilis. Mol Microbiol 2003, 49(4): I I35-I | 44.

36. Fuchs S, Pane-Farre J, Kohler C, Hecker M, Engelmann S: Anaerobic gene expression in Staphylococcus aureus. J Bacteriol 2007, 189(I I ):4275-4289.

37. Li M, Cha DJ, Lai Y, Villaruz AE, Sturdevant DE, Otto M: The antimicrobial peptide-sensing system aps of Staphylococcus aureus. Mol Microbiol 2007, 66(5): I |36-||47.

38. Charbonnier $Y$, Gettler B, Francois P, Bento M, Renzoni A, Vaudaux $P$, Schlegel W, Schrenzel J: A generic approach for the design of whole-genome oligoarrays, validated for genomotyping, deletion mapping and gene expression analysis on Staphylococcus aureus. BMC Genomics 2005, 6:95

39. Ramakrishnan R, Dorris D, Lublinsky $A$, Nguyen $A$, Domanus $M$, Prokhorova A, Gieser L, Touma E, Lockner R, Tata M, et al.: An assessment of Motorola CodeLink microarray performance for gene expression profiling applications. Nucleic Acids Res 2002, 30(7): 30 .

40. Hsu ST, Breukink E, Tischenko E, Lutters MA, de Kruijff B, Kaptein R, Bonvin AM, van Nuland NA: The nisin-lipid II complex reveals a pyrophosphate cage that provides a blueprint for novel antibiotics. Nat Struct Mol Biol 2004, I I ( I 0):963-967.

4l. Stone KJ, Strominger JL: Mechanism of action of bacitracin: complexation with metal ion and $\mathbf{C} 55$-isoprenyl pyrophosphate. Proc Natl Acad Sci USA 1971, 68(1 2):3223-3227.

42. Cotroneo N, Harris R, Perlmutter N, Beveridge T, Silverman JA: Daptomycin exerts bactericidal activity without lysis of Staphylococcus aureus. Antimicrob Agents Chemother 2008, 52(6):2223-2225.

43. Breukink E, Wiedemann I, van Kraaij C, Kuipers OP, Sahl H, de Kruijff B: Use of the cell wall precursor lipid II by a pore-forming peptide antibiotic. Science 1999, 286(5448):236I-2364.

44. Brotz H, Bierbaum G, Leopold K, Reynolds PE, Sahl HG: The lantibiotic mersacidin inhibits peptidoglycan synthesis by targeting lipid II. Antimicrob Agents Chemother I998, 42(I): I 54-I60.

45. Brotz H, Josten M, Wiedemann I, Schneider U, Gotz F, Bierbaum G Sahl HG: Role of lipid-bound peptidoglycan precursors in the formation of pores by nisin, epidermin and other lantibiotics. Mol Microbiol 1998, 30(2):317-327.

46. Muthaiyan A, Silverman JA, Jayaswal RK, Wilkinson BJ: Transcriptional profiling reveals that daptomycin induces the Staphylococcus aureus cell wall stress stimulon and genes responsive to membrane depolarization. Antimicrob Agents Chemother 2008, 52(3):980-990.

47. Allen NE, Hobbs JN, Alborn WE Jr: Inhibition of peptidoglycan biosynthesis in gram-positive bacteria by LY I46032. Antimicrob Agents Chemother 1987, 3 I (7): 1093-1099.

48. Sass V, Pag U, Tossi A, Bierbaum G, Sahl HG: Mode of action of human beta-defensin 3 against Staphylococcus aureus and transcriptional analysis of responses to defensin challenge. Int J Med Microbiol 2008, 298(7-8):619-633.

49. Sass P, Jansen A, Szekat C, Sass V, Sahl HG, Bierbaum G: The lantibiotic mersacidin is a strong inducer of the cell wall stress response of Staphylococcus aureus. BMC Microbiol 2008, 8: I86.

50. Rietkotter E, Hoyer D, Mascher T: Bacitracin sensing in Bacillus subtilis. Mol Microbiol 2008, 68(3):768-785.

51. Bacitracin - Substance Summary [http:// pubchem.ncbi.nlm.nih.gov/summary/summary.cgi?sid=48|4]

52. McAleese F, Wu SW, Sieradzki K, Dunman P, Murphy E, Projan S, Tomasz A: Overexpression of genes of the cell wall stimulon in clinical isolates of Staphylococcus aureus exhibiting vancomycin-intermediate- $S$. aureus-type resistance to vancomycin. | Bacteriol 2006, | 88(3): | | 20-|| 33.

53. Scherl A, Francois P, Charbonnier $Y$, Deshusses JM, Koessler T, Huyghe A, Bento M, Stahl-Zeng J, Fischer A, Masselot A, et al.: Exploring glycopeptide-resistance in Staphylococcus aureus: a combined proteomics and transcriptomics approach for the identification of resistance-related markers. BMC Genomics 2006, 7:296. 
54. Voyich JM, Braughton KR, Sturdevant DE, Whitney AR, Said-Salim B, Porcella SF, Long RD, Dorward DW, Gardner DJ, Kreiswirth BN, et al.: Insights into mechanisms used by Staphylococcus aureus to avoid destruction by human neutrophils. J Immunol 2005, I 75(6):3907-3919.

55. Garzoni C, Francois P, Huyghe A, Couzinet S, Tapparel C, Charbonnier Y, Renzoni A, Lucchini S, Lew DP, Vaudaux P, et al.: A global view of Staphylococcus aureus whole genome expression upon internalization in human epithelial cells. BMC Genomics 2007, 8: $17 \mid$.

56. Sass P, Bierbaum G: Native graS mutation supports the susceptibility of Staphylococcus aureus strain SG5II to antimicrobial peptides. Int J Med Microbiol 2009, 299(5):3 I3-322.

57. Ordway D, Viveiros M, Leandro C, Jorge Arroz M, Molnar J, Kristiansen JE, Amaral L: Chlorpromazine has intracellular killing activity against phagocytosed Staphylococcus aureus at clinical concentrations. J Infect Chemother 2002, 8(3):227-23I.

58. Kuroda M, Ohta T, Uchiyama I, Baba T, Yuzawa H, Kobayashi I, Cui L, Oguchi A, Aoki K, Nagai Y, et al:: Whole genome sequencing of meticillin-resistant Staphylococcus aureus. Lancet 2001, 357(9264): 1225-1240.

59. Baba T, Takeuchi F, Kuroda M, Yuzawa H, Aoki K, Oguchi A, Nagai Y, Iwama N, Asano K, Naimi T, et al:: Genome and virulence determinants of high virulence community-acquired MRSA. Lancet 2002, 359(9320): 1819-1827.

60. Gill SR, Fouts DE, Archer GL, Mongodin EF, Deboy RT, Ravel J, Paulsen IT, Kolonay JF, Brinkac L, Beanan M, et al.: Insights on evolution of virulence and resistance from the complete genome analysis of an early methicillin-resistant Staphylococcus aureus strain and a biofilm-producing methicillin-resistant Staphylococcus epidermidis strain. I Bacteriol 2005 I 87(7):2426-2438.

61. NCBI [http://www.ncbi.nlm.nih.gov/entrez/viewer.fcgi?db=nuc core\&id $=88193823$

62. Diep BA, Gill SR, Chang RF, Phan TH, Chen JH, Davidson MG, Lin F, Lin J, Carleton HA, Mongodin EF, et al:: Complete genome sequence of USA300, an epidemic clone of communityacquired meticillin-resistant Staphylococcus aureus. Lancet 2006, 367(95 I 2):73|-739.

63. Holden MT, Feil EJ, Lindsay JA, Peacock SJ, Day NP, Enright MC, Foster TJ, Moore CE, Hurst L, Atkin R, et al.: Complete genomes of two clinical Staphylococcus aureus strains: evidence for the rapid evolution of virulence and drug resistance. Proc Natl Acad Sci U S A 2004, I 0 I (26):9786-9I.

64. Koessler T, Francois $P$, Charbonnier $Y$, Huyghe A, Bento M, Dharan S, Renzi G, Lew D, Harbarth S, Pittet D, et al.: Use of oligoarrays for characterization of community-onset methicillin-resistant Staphylococcus aureus. J Clin Microbiol 2006, 44(3): I040- 1048.

65. Renzoni A, Barras C, Francois P, Charbonnier Y, Huggler E, Garzoni C, Kelley WL, Majcherczyk P, Schrenzel J, Lew DP, et al.: Transcriptomic and functional analysis of an autolysis-deficient, teicoplanin-resistant derivative of methicillin-resistant Staphylococcus aureus. Antimicrob Agents Chemother 2006, 50(9):3048-306I.

66. Churchill GA: Using ANOVA to analyze microarray data. Biotechniques 2004, 37(2): 173-175.

67. Hyyryläinen HL, Pietiainen M, Lunden T, Ekman A, Gardemeister M, Murtomaki-Repo S, Antelmann H, Hecker M, Valmu L, Sarvas M, et al.: The density of negative charge in the cell wall influences twocomponent signal transduction in Bacillus subtilis. Microbiology 2007, I 53(Pt 7):21 26-2136.

68. Vagner $V$, Dervyn E, Ehrlich SD: A vector for systematic gene inactivation in Bacillus subtilis. Microbiology 1998, 144:3097-3 I04.

69. Bae T, Schneewind O: Allelic replacement in Staphylococcus aureus with inducible counter-selection. Plasmid 2005, 55:58-63.

70. Pajunen MI, Pulliainen AT, Finne J, Savilahti H: Generation of transposon insertion mutant libraries for Gram-positive bacteria by electroporation of phage Mu DNA transposition complexes. Microbiology 2005, I 5 I(Pt 4): |209-|2|8.

7I. von Eiff C, McNamara P, Becker K, Bates D, Lei XH, Ziman M, Bochner BR, Peters G, Proctor RA: Phenotype microarray profiling of Staphylococcus aureus menD and hemB mutants with the small-colony-variant phenotype. I Bacteriol 2006, I 88(2):687-693.
72. Baba T, Bae T, Schneewind O, Takeuchi F, Hiramatsu K: Genome sequence of Staphylococcus aureus strain Newman and comparative analysis of staphylococcal genomes: polymorphism and evolution of two major pathogenicity islands. J Bacteriol 2008, 190(I):300-310.

73. Kreiswirth BN, Lofdahl S, Betley MJ, O'Reilly M, Schlievert PM, Bergdoll MS, Novick RP: The toxic shock syndrome exotoxin structural gene is not detectably transmitted by a prophage. Nature 1983, 305(5936):709-7|2.
Publish with Biomed Central and every scientist can read your work free of charge

"BioMed Central will be the most significant development for disseminating the results of biomedical research in our lifetime. "

Sir Paul Nurse, Cancer Research UK

Your research papers will be:

- available free of charge to the entire biomedical community

- peer reviewed and published immediately upon acceptance

- cited in PubMed and archived on PubMed Central

- yours - you keep the copyright 